6,82 \%. Вариация признака "стекловидность" у сортов CV от 2,18 до 3.84. Вариация признака "трещиноватость" была сильной у сортов и находилась в пределе от 22,3 \% до 121,4 \%. По признаку "содержание целого ядра в крупе" вариация была высокой у сорта ВНИИР 6378 (CV 26,7), у остальных сортов она была средней - CV 11,8-18,3.

Таблица 3. Средние значения и вариабельность технологических признаков качества зерна сортов риса селекции ВНИИ риса, урожай 2015-2017 гг.

\begin{tabular}{|l|c|c|c|c|c|c|c|c|}
\hline \multirow{2}{*}{ Сорт } & \multicolumn{2}{|c|}{$\begin{array}{c}\text { Масса а.с. } \\
1000 \text { зерен, г }\end{array}$} & \multicolumn{2}{c|}{ Стекловидность, \% } & \multicolumn{2}{|c|}{ Трещиноватость, \% } & $\begin{array}{c}\text { Содержание це- } \\
\text { лого ядра, \% }\end{array}$ \\
\cline { 2 - 10 } & CV & Cp. & CV & Cp. & CV & Cp. & CV & Cp. \\
\hline Кураж & 1,78 & 24,5 & 3,84 & 94 & 50,0 & 10 & 18,3 & 80,8 \\
\hline ВНИИР 6463 & 2,26 & 24,6 & 3,84 & 94 & 121,4 & 8 & 13,8 & 73,9 \\
\hline ВНИИР 6378 & 4,68 & 26,3 & 2,18 & 93 & 41,7 & 13 & 26,7 & 77,4 \\
\hline ВНИИР 6514 & 6,82 & 24,2 & 3,19 & 94 & 22,3 & 9 & 11,8 & 81,8 \\
\hline
\end{tabular}

Низкая вариабельность сортов по признакам качества характеризует высокую их стабильность. В связи с этим наиболее стабильными по признаку крупности зерна являются Кураж и ВНИИР 6463, по признаку трещиноватости - ВНИИР 6514, по признаку содержания целого ядра в крупе - ВНИИР 6463 и ВНИИР 6514. Однако, у сорта ВНИИР 6463 очень высокая вариабельность по трещиноватости.

Лучшим в 2015-2017 гг. был признан сорт ВНИИР 6514, который показал высокие технологические признаки по всем годам исследований. Этот стабильный сорт, который практически не реагирует на изменяющиеся погодно-климатические условия в отношении признаков качества зерна, может быть рекомендован для дальнейших испытаний в целях передачи в Госкомиссию по испытанию селекционных достижений, а также использован в селекции в качестве источника ценных признаков качества.

\section{Список литературы}

1. ГОСТ 10842-89. Зерно зерновых и бобовых культур и семена масличных культур. Метод определения массы 1000 зерен и 1000 семян; введ. 1999-
07-01. - Москва: Межгос. Совет по стандартизации, метрологии и сертификации; Москва: Изд-во стандартов, - Зерно. Методы анализа, 2009. - 7 с.

2. ГОСТ 10843-76. Метод определения пленчатости; введ. 1976-07-01. - Москва: Межгос. Совет по стандартизации, метрологии и сертификации; Москва: Изд-во стандартов, 2009. - 11 с.

3. ГОСТ 10987-76. Метод определения стекловидности; введ. 1977-06-01. - Москва: Межгос. Совет по стандартизации, метрологии и сертификации; Москва: Изд-во стандартов, 2009. - 53 с.

4. Костылев, П.И., Краснова, Е.В. Новые сорта риса Вирасан и Пируэт / П.И. Костылев, Е.В. Краснова // Аграрная наука евро-северо-востока. 2018. T.3 (64) - C44-48.

5. Juliano B.O. Rice chemistry and quality. - PhilRicee, 2003. - 480 p. Tomar J.B. Studies on the inheritance of kernel size and its association with physical and chemical quality characters in rice (Oryza sativa L). // Z. Pflanzenzuhtg. - 1985. - № 95. P. 361-366.

\title{
NANOGOLD AND ITS CONJUGATES IN IMMUNOCHROMATOGRAPHY: SYNTHESIS, ANALYSIS, SEPARATION, CONJUGATION WITH MACROMOLECULES
}

Zaraysky Evgeniy.I.

Ph. D. IAM RAS Moscow

DOI: $10.31618 /$ ESU.2413-9335.2018.3.57.42-47

ABSTRACT: The review analyzes current data on methods for producing gold nanoparticles, their physicochemical properties and use in biomedical research. Methods for the synthesis of gold nanoparticles of various sizes, their study and separation, as well as conjugation with antibodies and antigens are considered. Such nanoconjugates are used in a wide range of immunochromatographic biosensors.

Key words: nanogold, biosynthesis, immunochromatography.

A very important component of EM systems is a marker, in which the most commonly used particles are colloidal gold. Due to the unique physical and chemical properties, gold nanoparticles have found wide application in various fields of biochemistry, medicine, analytical chemistry, etc. [1-6]. Gold nanoparticles have high surface energy, which determines the possibility of their modification to impart the desired physical and chemical properties [7].

Synthesis of colloidal gold using low molecular weight reducing agents
Methods for producing colloidal gold can be divided into two main areas: the disintegration of metallic gold and the condensation of gold atoms into particles. The second approach is more common due to the greater homogeneity in size and shape of the particles obtained by this method. This approach is based on the reduction of gold from halides, as a rule, of hydrochloric acid (CHLC; HAuCl4) [8]. The use of more than one hundred reducing agents for the production of colloidal gold in this way has been described, among them: 
formaldehyde, ethyl alcohol, white phosphorus, ascorbic acid, ethylenediaminetetraacetic acid, sodium borohydride, etc. Sodium citrate has become the most common as a reducing agent. The method of sodium citrate reduction by citrate proposed by Turkevich in 1951 [9] and refined by Frances in 1973 [10] has several advantages: a simple and reproducible synthesis procedure, the ability to produce particles in a wide range of sizes $(10-150 \mathrm{~nm})$, the stability of the colloid due to the stabilization of particles with citrate ions. Citrate ions can be easily replaced by other molecules, so this stabilization does not limit the possibility of surface modification of the particles.

The citrate reduction reaction can be represented as the following scheme:

$\mathrm{HAuCU}+\mathrm{Na} 3 \mathrm{C} 6 \mathrm{H} 50 \mathrm{y}+\mathrm{H} 2 \mathrm{O} \sim \mathrm{Au}+\mathrm{CO} 2+$ $\mathrm{NaCl}+\mathrm{HCl}$

There are two key processes in the formation of short particles during the reduction of HLCs: the formation of nuclei (centers of crystallization) and their growth [11]. The ratio between the speeds of these processes determines the size of the particles produced. With the rapid formation of embryos, a large number of small particles are formed, whereas with a low nucleation rate, a relatively small number of large particles are obtained. Reducing the reactivity of the reducing agent as a whole results in larger particles. Similarly, an increase in the concentration of reducing agent leads to a decrease in the average particle diameter [8].

According to the scheme of restoration of ZHVK citrate, presented in Fig. 2, in the first stage, the formation of intermediate acetone dicarboxylate occurs. At the same time, $\mathrm{Au} 3+$ ions are reduced to $\mathrm{Au}+$. Then polymolecular complexes are formed between acetone dicarboxylate and $\mathrm{Au}+$, which leads to a local increase in the concentration of gold ions (see Fig. 2B).

Subsequently Au disproportionation occurs to $\mathrm{AuO}+$ and $\mathrm{Au} 3+$. The reduction of gold to the zero oxidation state causes the formation and growth of nuclei and the formation of final particles [12].

The dimensional characteristics of the resulting product are also influenced by the order of addition of the reactants, the intensity of mixing, the temperature, the duration of the reaction and the $\mathrm{pH}$ of the medium.

The low nucleation rate leads to a wider particle size distribution. The resulting particles can partially aggregate, increasing the heterogeneity of the drug. Therefore, stabilization of particles in solution is also important for high homogeneity.

Since the dimensional characteristics of the synthesis product are affected by the $\mathrm{pH}$ of the reaction medium, which changes during the reaction, Schulz et al. [12] proposed to carry out the restoration of ZHVK in citrate buffer instead of the usual solution of sodium citrate. This made it possible to significantly narrow the size distribution of the synthesized particles (the coefficient of variation of the particle diameter decreased to $6 \%$ compared to $12.5 \%$ for the unmodified method). However, since to obtain larger particles, it is necessary to use lower concentrations of citrate ions, and thus lower the molarity of the buffer and its buffer capacity, this approach is effective only in obtaining colloidal gold with a diameter of not more than $17 \mathrm{~nm}$.
With the Turkevich-French method, particles with a diameter of up to $150 \mathrm{~nm}$ can be obtained. However, this barrier can be overcome by using sequential (multistage) build-up. At the same time, along with an increase in the diameter (up to several hundred nanometers), the particle size uniformity also increases [13]. The essence of the method is that first the reaction is carried out under conditions of rapid nucleation to obtain a monodisperse preparation with a small particle diameter. The transition from the formation of

embryos and their growth is provided by changing conditions. For example, the intensive formation of embryos and their growth is observed in a boiling solution. However, if the temperature is raised to about $90 \%$, the formation of new crystallization centers is inhibited, while the growth of existing centers continues. Thus, if the previously synthesized seed preparation is placed in a mixture of CLC and citrate, without boiling, the nanoparticles will gradually increase in size until CCP consumption. The slower the build-up, the narrower the particle size distribution obtained. The concentration of the seed must exceed 21011 particles per ml, otherwise the formation of new crystallization centers cannot be avoided.

According to the Lamer mechanism [14,15], the growth of nanoparticles includes two periods:

1. focusing, during which the particle size increases rapidly, and the size distribution narrows;

2. defocusing, when the growth rate of particles decreases sharply, and the size distribution expands.

The second period, during which small particles dissolve, and large ones increase due to the released gold, is called Ostwald ripening. It is because of this maturation that particles with a diameter of less than 10 $\mathrm{nm}$ are difficult to obtain using the Turkevich-France method. The transition time between two processes depends on the reaction temperature and the concentration of the precursor (CLC) [16]. With a high

concentration of the precursor, the focusing period increases and, as a result, the homogeneity of the drug increases. However, with an increase in the concentration of the precursor, the probability of the formation of additional crystallization centers, leading to the appearance of particles of smaller size, also increases. This fact is one more confirmation of the importance of the choice in the synthesis of the optimal concentration of CLC. You can also increase the focusing period by lowering the temperature.

The importance of obtaining homogeneous preparations of colloidal gold is associated, for example, with the fact that smaller gold particles have a lower binding constant with respect to biomolecules [17], and larger ones (more than $40 \mathrm{~nm}$ ) are prone to agglutination. Therefore, the presence of too small or too large particles adversely affect the stability of the drug. For ICA, the use of gold nanoparticles with a diameter in the range of 20-40 $\mathrm{nm}$ is optimal [18, 19]. cules.

Conjugation of colloidal gold with macromole-

As a rule, gold particles are modified using proteins, nucleic acids, etc. to give them greater stability and various functional properties [4; 20]. In complexes with bioreceptor molecules (antibodies, aptamers, etc.), 
short-circuits are used as markers for solving analytical problems [21].

The stabilization of colloidal gold by macromolecules to protect against aggregating reagents is due to the structure of the gold surface and its immediate environment. The surface of the gold particle is negatively charged (surface potential of about $-50 \mathrm{mV}$ ) due to the layer of gold chloride anions that were not fully restored during synthesis (Fig. 3). Depending on the method of synthesis and composition of the reaction medium, other anions may be present on the surface. For example, as already noted, citrate ions are present on the surface of gold particles synthesized by the citrate method. Counterions (protons, metal cations, etc.) are located in the next layer around the anionic layer. This is the formation of a double ionic shell around the nanoparticles, which generates repulsive forces between them. Due to the described processes, colloidal gold is stable only in solutions with low ionic strength, since the addition of electrolytes compensates for the excess charge of the ionic shells and lowers the energy barrier of repulsion, which leads to contact of the surfaces and adhesion of particles.

The polymer coating of the surface of the particle allows you to save the layer that separates the gold surface. As a result, the colloid becomes less sensitive to the ionic strength of the solution and other factors that can cause aggregation.

The interaction of macromolecules with $\mathrm{CZ}$ depends on the chemical nature of the substance to be sorbed, the composition of the medium, and other factors. Electrostatic, hydrophobic, van der Waals and donor-acceptor interactions can contribute to this process [8]. It is also known that gold has a high affinity for sulfur-containing chemical groups, which leads to the formation of a self-assembled monolayer of thiol-containing molecules on gold surfaces [24]. Effective stabilizing agents for colloidal gold are proteins. Even a simple physical sorption of proteins on the surface of gold is characterized by a high complexation constant: ( $\mathrm{Kd}$ - up to $10-9 \mathrm{M})[17 ; 25]$. Due to the presence of many groups of proteins of different chemical nature in proteins, their interaction with the surface of the particles occurs through several binding sites and several mechanisms.

Covalent immobilization can also be used to prepare colloidal conjugates. However, it is precisely physical adsorption that is most prevalent because of its methodological simplicity and minimal impact on the structure and properties of the protein [20]. The main disadvantage of non-covalent immobilization is the possible partial desorption of protein molecules from the surface and, as a consequence, a decrease in the functional activity of the conjugate [26; 27].

\section{Characteristics of the composition of conjugates of colloidal gold}

By now, many methods have been proposed for experimentally measuring the number of molecules sorbed on the surface of a nanoparticle [28]. This series includes spectroscopic methods (absorption [29], emission [30], fluorescent [31], and others), mass spectrometry [32], recording of light scattering (Raman [33], dynamic light scattering [34], etc.), analytical separation methods (chromatography [35], electrophoresis [36], analytical ultracentrifugation [37], cross-sectional fractionation [38], etc.). Consider the possibility of applying these methods to solve the problems of determining the composition of short-circuit conjugates.

\section{Methods for characterizing colloidal conjugates}

A variety of spectroscopic methods differ from each other in the energy of the radiation used (infrared, optical, X-ray, etc.), as well as in the recorded parameter: the intensity of absorption of radiation (absorption methods) or its emission (emission methods) or position offset spectral peaks. Conjugates are studied using these methods either with the help of labeled molecules or using their own spectra of nanoparticles and immobilized molecules. An example of the first approach is the work of De Roe et al., Who determined the composition of CP conjugates with proteins labeled with a radioactive label [30]. This technique allows direct detection of protein molecules on the surface of the conjugate, since nanoparticles have little effect on the intensity of X-ray radiation. The second approach was applied, for example, Kaur et al. [29], who studied the displacement of the main peak of absorption of a shortcircuit caused by the immobilization of proteins on the surface of particles.

Of particular interest is fluorescence spectroscopy, implemented using the fluorescent properties of both the label and the sorbed molecules themselves. For example, McKenzie et al. the amount of labeled antibodies and nucleic acids was determined by the fluorescence of the label after it was isolated from the conjugate by enzymatic hydrolysis [39]. In characterizing the composition of conjugates, the presence of strongly fluorescent amino acid, tryptophan, is often used in protein molecules. Since colloidal particles are strong modulators of fluorescence, immobilization of protein molecules on them leads to significant changes in its spectrum, the registration of which is proposed by a number of authors $[17 ; 40 ; 41]$.

Mass spectrometry in the format of matrix-activated laser desorption / ionization with a time-of-flight analyzer (MALDI-TOF MS) is successfully used to determine the composition of short-circuit conjugates. This method allows one to simultaneously characterize several conjugated compounds due to the difference in the ionized molecules formed from them. So, Hong et al. using MALDI-TOF MS, bovine serum albumin and glutathione-S-transferase conjugated with gold particles were simultaneously recorded [32]. The proteins in the conjugate with $\mathrm{CP}$ were subjected to enzymatic hydrolysis, then the resulting protein fragments were mixed with standard preparations labeled with a heavy isotope, and based on a comparison of the concentrations of labeled and unlabeled fragments, they concluded that the initial composition of the conjugates was. The disadvantages of the method include the high cost and complexity of the analysis procedure.

The methods of recording light scattering make it possible to characterize functionalized nanoparticles without the use of labels $[34 ; 42 ; 43]$. The main advantages of these methods are: simplicity, the ability to characterize the conjugates in the initial solution, as well as the ability to record immobilization in real time. 
However, the accuracy of the results of such studies is low, since not only the composition, but also the structure of the conjugate affects the recorded scattering parameters. In this regard, drugs with different loads of immobilized proteins can give the same recorded characteristics of scattering, and the calculation of the number of sorbed molecules is based on a number of assumptions. It should also be noted that the measured parameter of the particles (for example, in dynamic light scattering

- the hydrodynamic radius) is indirect and reflects the properties of not only the conjugate, but also the hydration shell formed around it. Differences in dimensional characteristics obtained by different methods were noted in a number of papers. So, Bell et al. note that for the same preparation of colloidal gold particles the average diameter was $20.1 \mathrm{~nm}$ (transmission electron microscopy), $25.7 \mathrm{~nm}$ (dynamic light scattering) and $24.0 \mathrm{~nm}$ (nanoparticle trajectory analysis) [34].

Methods of separation and fractionation of nanoparticles in the analysis of colloidal conjugates.

Methods for the separation of mixtures are used for the analysis of colloidal conjugates, either alone or in combination with other approaches.

Chromatographic methods are often used to separate functionalized colloidal particles [28]. These methods are characterized by high separation efficiency of particles, but their use is often associated with the appearance of artifacts associated with the interaction of particles with a stationary phase.

Various types of electrophoresis, capillary electrophoresis, gel electrophoresis, etc.,

are widely used both to separate colloidal conjugates and to analyze their composition, including complex multicomponent mixtures [28, 36].

Analytical centrifugation, in addition to the possibility of separating colloidal particles, allows you to determine the size, size distribution and shape of particles. Also, this method can obtain some information about the conformation and structural changes of biomolecules immobilized on the surface of particles [37; 44].

The method of fractionation in a transverse field is based on the application of a field (electric, gravitational, centrifugal, magnetic, thermal, etc.), which is directed perpendicular to the flow of fluid through a long narrow channel [38]. Due to differences in the mobility of particles under the action of a field of one or another nature, the nanomaterial passing through the channel is fractionated. The method allows the separation of particles in a wide range of sizes - from $1 \mathrm{~nm}$ to 1 micron.

\section{Interaction of proteins with colloidal gold}

Despite the intensive development of research, the interaction of proteins with short-circuits still raises many questions. Many works contain data that at first glance may seem contradictory. So, in $[43 ; 45 ; 46]$ утверждается, что белки образуют монослой на поверхности коллоидного золота, а в работах [17; 47] утверждается, что имеет место полислойная иммобилизация. B работе De Roe и соавт. [30] показано, что белок А взаимодействует с коллоидным золотом с равновесной константой диссоциации 343,9
нМ, тогда как в работе [26] утверждается, что константа диссоциации при низких концентрациях белка А составляет 2-3 нМ, а при высоких повышается до 500-900 нМ, хотя оба исследования проведены с использованием одного и того же метода рентгеновской спектроскопии. Значительные различия констант взаимодействия с коллоидным золотом наблюдаются и для других белков - они могут достигать пяти порядков [25; 30; 41; 43; 48]. Например, для конъюгата БСА и КЗ значения константы диссоциации, определенные на основании тушения флуоресценции триптофана, варьируют от 0,88 10-4 М [49] до 110-9 М [25].

Открытым также остается вопрос о кооперативности сорбции белков на коллоидных частицах. Так, данные, полученные Lacerda и соавт. [17], демонстрируют, что в зависимости от размера золотых частиц сорбция на них белков может характеризоваться как положительной, так и отрицательной кооперативностью. Например, для инсулина на частицах золота диаметром 100 нм наблюдается положительная кооперативность сорбции (коэффициент Хилла $n=3,64)$, а на частицах диаметром 20 нм отрицательная $(\mathrm{n}=0,63)$.

Эти различия могут быть объяснены недостаточной точностью некоторых методов, возможными изменениями структуры конъюгатов в ходе экспериментов, а также использованием неунифицированных наночастиц, полученных в разных условиях [47].

Измерение констант иммунного взаимодействия методом ППР

Поверхностный плазмонный резонанс (ППР) возбуждение коллективных колебаний электронов проводимости на границе раздела сред, одна из которых имеет отрицательную действительную часть диэлектрической проницаемости. Кванты таких колебаний электронного газа получили название поверхностных плазмонов [50]. Условия возникновения ППР чрезвычайно чувствительны к составу среды вблизи границы раздела, что позволяет с помощью ППР детектировать образование межмолекулярных комплексов в режиме реального времени без использования меток с минимальной пробоподготовкой [51-54].

ППР-биосенсоры чаще всего классифицируют по используемым в них методам возбуждения поверхностных плазмонов. Основные типы схем для этого возбуждения - схемы на основе призм с высоким показателем преломления (метод Отто-Кречманна), волноводов и дифракционных решеток. Реже используют другие приспособления, например, фотонные кристаллы. Возможно также комбинирование нескольких схем возбуждения в одном устройстве [55]. Отдельно следует упомянуть методы, основанные на использовании явления локального поверхностного плазмонного резонанса (ЛППР) и методы, использующие влияние эффекта ППР/ЛППР на такие оптические процессы, как адсорбция, флуоресценция или рамановское рассеяние [56]. 


\section{Список литературы}

1. Sperling RA, Gil PR, Zhang F., Zanella M., Parak WJ Biological applications of gold nanoparticles // Chemical Society Reviews. - 2008. - V. 37, No 9. - P. 1896-1908.

2. Boisselier E., Astruc D. Gold nanoparticles in nanomedicine: preparations, imaging, diagnostics, therapies and toxicity // Chemical Society Reviews. 2009. - V. 38, No 6. - P. 1759-1782.

3. Saha K., Agasti SS, Kim C., Li X., Rotello VM Gold nanoparticles in chemical and biological sensing // Chemical Reviews. - 2012. - V. 112, No 5. P. 2739-2779.

4. Zeng SWYKT, Roy I., DinhX.P., Yu X., Luan F. A review on functionalized gold nanoparticles for biosensing applications // Plasmonics. - 2011. - V. 6, No 3. - P. 491-506.

5. Dreaden EC, Alkilany AM, Huang X., Murphy CJ, El-Sayed MA The golden age: gold nanoparticles for biomedicine // Chemical Society Reviews. 2012. - V. 41, No 7. - P. 2740-2779.

6. Dykman L., Khlebtsov N. Gold nanoparticles in biomedical applications: recent advances and perspectives // Chemical Society Reviews. - 2012. - V. 41, No 6. - P. 2256-2282.

7. Daniel M.-C., Astruc D. Gold nanoparticles: assembly, supramolecular chemistry, quantum-size-related properties, and applications toward biology, catalysis, and nanotechnology // Chemical Reviews. - 2004 - V. 104, No 1. - P. 293-346.

8. Дыкман Л.А., Богатырев В.А., Щеголев С.Ю., Хлебцов Н.Г. Золотые наночастицы: синтез, свойства, биомедицинское применение // М.: Наука. - 2008. - 319 с.

9. Turkevich J., Stevenson PC, Hillier J. A study of the nucleation and growth processes in the synthesis of colloidal gold // Discussions of the Faraday Society. - 1951. - V. 11. - P. 55-75.

10. Frens G. Controlled nucleation for the regulation of the particle size in monodisperse gold suspensions // Nature. - 1973. - V. 241, No 105. - P. 20-22.

11. Thanh NT, Maclean N., Mahiddine S. Mechanisms of nucleation and growth of nanoparticles in solution // Chemical Reviews. - 2014. - V. 114, No 15. P. 7610-7630.

12. Schulz F., Homolka T., Bastus NG, Puntes V., Weller H., Vossmeyer T. Little adjustments significantly improve the Turkevich synthesis of gold nanoparticles // Langmuir. - 2014. - V. 30, No 35. - P. 10779-10784.

13. Bastus NG, Comenge J., Puntes V. Kinetically controlled seeded growth synthesis of citrate-stabilized gold nanoparticles of up to $200 \mathrm{~nm}$ : size focusing versus Ostwald ripening // Langmuir. - 2011. - V. 27, No 17. - P. 11098-11105.

11.LaMer VK, Dinegar RH Theory, production and mechanism of formation of monodispersed hydrosols // Journal of the American Chemical Society. 1950. - V. 72, No- P. 4847-4854.

14. Reiss H. The growth of uniform colloidal dispersions // The Journal of Chemical Physics. - 1951. V. 19, No 4. - P. 482-487.

15. Peng X., Wickham J., Alivisatos A. Kinetics of II-VI and III-V colloidal semiconductor nanocrystal growth:'Focusing' of size distributions // Journal of the
American Chemical Society. - 1998. - V. 120, No LBNL. - P. 41792.

16. Lacerda SHDP, Park JJ, Meuse C., Pristinski D., Becker ML, Karim A., Douglas JF Interaction of gold nanoparticles with common human blood proteins // ACS Nano. -

17. Lou S., Ye J.-Y., Li K.-Q., Wu A. A gold nanoparticle-based immunochromatographic assay: the influence of nanoparticulate size // Analyst. - 2012. - V. 137, No 5. - P. 11741181.

18. Бызова Н., Жердев А., Ескендирова С., Балтик К., Унышева Г., Муканов К., Раманкулов Е., Дзантиев Б. Разработка иммунохроматографической тест-системы для экспрессной детекции липополисахаридного антигена и клеток возбудителя бруцеллеза крупного рогатого скота // Прикладная биохимия и микробиология. - 2012. - Т. 48, № 6. - С. 653-661.

19. Sapsford KE, Algar WR, Berti L., Gemmill KB, Casey BJ, Oh E., Stewart MH, Medintz IL Functionalizing nanoparticles with biological molecules: developing chemistries that facilitate nanotechnology // Chemical Reviews. - 2013. - V. 113, No 3. - P. 19042074.

20. Salata OV Applications of nanoparticles in biology and medicine // Journal of Nanobiotechnology. 2004. - V. 2, No 1. - P. 1.

21. Faraday M. The Bakerian lecture: experimental relations of gold (and other metals) to light // Philosophical Transactions of the Royal Society of London. - 1857. - V. 147. - P. 145

181.

22. Mays DC Using the Quirk-Schofield diagram to explain environmental colloid dispersion phenomena // Journal of Natural Resources \& Life Sciences Education. - 2007. - V. 36, No 1. - P. 45-52.

23. Sellers H., Ulman A., Shnidman Y., Eilers JE Structure and binding of alkanethiolates on gold and silver surfaces: implications for self-assembled monolayers // Journal of the American Chemical Society. 1993. - V. 115, No 21. - P. 9389-9401.

24. Sen T., Haldar KK, Patra A. Au nanoparticlebased surface energy transfer probe for conformational changes of BSA protein // The Journal of Physical Chemistry C. - 2008. - V. 112, No 46. - P. 1794517951.

25. Ghitescu L., Bendayan M. Immunolabeling efficiency of protein A-gold complexes // Journal of Histochemistry \& Cytochemistry. - 1990. - V. 38, No 11. - P. 1523-1530.

26. Kramarcy NR, Sealock R. Commercial preparations of colloidal gold-antibody complexes frequently contain free active antibody // Journal of Histochemistry \& Cytochemistry. - 1991. - V. 39, No 1. - P. 37-39.

27. Sapsford KE, Tyner KM, Dair BJ, Deschamps JR, Medintz IL Analyzing nanomaterial bioconjugates: a review of current and emerging purification and characterization techniques // Analytical Chemistry. - 2011. - V. 83, No 12. - P. 44534488.

28. Kaur K., Forrest JA Influence of particle size on the binding activity of proteins adsorbed onto gold nanoparticles // Langmuir. - 2012. - V. 28, No 5. - P. 2736-2744. 
29. De Roe C., Courtoy PJ, Baudhuin P. A model of protein-colloidal gold interactions // Journal of Histochemistry \& Cytochemistry. - 1987. - V. 35, No 11. P. 1191-1198.

30. Sotnikov DV, Zherdev AV, Dzantiev BB Development and application of a label-free fluorescence method for determining the composition of gold nanoparticle-protein conjugates // International Journal of Molecular Sciences. - 2014. - V. 16, No 1. - P. 907923.

31. Hong S.-H., Ji KM, Ahn J.-H., Yeo W.-S. Multiplexed quantification of surface-bound proteins on gold nanoparticles // Analytical Methods. - 2013. V. 5, No 16. - P. 38163818.

32. Zhang D., Neumann O., Wang H., Yuwono VM, Barhoumi A., Perham M., Hartgerink J., WittungStafshede P., Halas NJ Gold nanoparticles can induce the formation of protein-based aggregates at physiological pH // Nano Letters. - 2009. - V. 9, No 2. - P. 666671.

33. Bell NC, Minelli C., Shard AG Quantitation of IgG protein adsorption to gold nanoparticles using particle size measurement // Analytical Methods. - 2013. V. 5, No 18.P. 4591-4601.

34. Mullen DG, Desai AM, Waddell JN, Cheng X.-M., Kelly CV, McNerny DQ, Majoros IJ, Baker Jr JR, Sander LM, Orr BG The implications of stochastic synthesis for the conjugation of functional groups to nanoparticles // Bioconjugate Chemistry. - 2008. - V. 19, No 9. - P. 1748-1752.

35. Pellegrino T., Sperling RA, Alivisatos A., Parak WJ Gel electrophoresis of gold-DNA nanoconjugates // BioMed Research International. - 2008. - T. 2007.

36. Lees EE, Gunzburg MJ, Nguyen T.-L., Howlett GJ, Rothacker J., Nice EC, Clayton AH, Mulvaney P. Experimental determination of quantum dot size distributions, ligand packing densities, and bioconjugation using analytical ultracentrifugation // Nano letters. -- V. 8, No 9. - P. 2883-2890.

37. Cho TJ, Hackley VA Fractionation and characterization of gold nanoparticles in aqueous solution: asymmetric-flow field flow fractionation with MALS, DLS, and UV-vis detection // Analytical and Bioanalytical Chemistry. - 2010. - V. 398, No 5. - P. 20032018.

38. McKenzie F., Steven V., Ingram A., Graham D. Quantitation of biomolecules conjugated to nanoparticles by enzyme hydrolysis // Chemical Communications. - 2009. No 20. - P. 2872-2874.

39. Iosin M., Canpean V., Astilean S. Spectroscopic studies on $\mathrm{pH}$-and thermally induced conformational changes of bovine serum albumin adsorbed onto gold nanoparticles // Journal of Photochemistry and Photobiology A: Chemistry. - 2011. - V. 217, No 2. - P. 395-401.

40. Naveenraj S., Anandan S., Kathiravan A., Renganathan R., Ashokkumar M. The interaction of sonochemically synthesized gold nanoparticles with serum albumins // Journal of Pharmaceutical and Biomedical Analysis. - 2010. - V. 53, No 3. - P. 804-810.

41. Jans H., Liu X., Austin L., Maes G., Huo Q. Dynamic light scattering as a powerful tool for gold nanoparticle bioconjugation and biomolecular binding studies // Analytical Chemistry.2009. - V. 81, No 22. P. 9425-9432.

42. Dominguez-Medina S., McDonough S., Swanglap P., Landes CF, Link S. In situ measurement of bovine serum albumin interaction with gold nanospheres // Langmuir.

43. Calabretta M., Jamison JA, Falkner JC, Liu Y., Yuhas BD, Matthews KS, Colvin VL Analytical ultracentrifugation for characterizing nanocrystals and their bioconjugates // Nano Letters. - 2005. - V. 5, No 5. - P. 963-967.

44. Casals E., Pfaller T., Duschl A., Oostingh GJ, Puntes V. Time evolution of the nanoparticle protein corona // ACS Nano. - 2010. - V. 4, No 7. - P. 36233632 .

45. Tsai D.-H., DelRio FW, Keene AM, Tyner KM, MacCuspie RI, Cho TJ, Zachariah MR, Hackley VA Adsorption and conformation of serum albumin protein on gold nanoparticles investigated using dimensional measurements and in situ spectroscopic methods // Langmuir. - 2011. - V. 27, No 6. - P. 2464-2477.

46. Chakraborty S., Joshi P., Shanker V., Ansari Z., Singh SP, Chakrabarti P. Contrasting effect of gold nanoparticles and nanorods with different surface modifications on the structure and activity of bovine serum albumin // Langmuir. - 2011. - V. 27, No 12. - P. 77227731 .

47. Brewer SH, Glomm WR, Johnson MC, Knag MK, Franzen S. Probing BSA binding to citrate-coated gold nanoparticles and surfaces // Langmuir. - 2005. V. 21, No 20. - P. 9303-9307.

48. Naveenraj S., Anandan S. Binding of serum albumins with bioactive substances- nanoparticles to drugs // Journal of Photochemistry and Photobiology C: Photochemistry Reviews. - 2013. - V. 14. - P. 53-71.

49. Handbook of Surface Plasmon Resonance. I Schasfoort RB, Tudos AJ London: Royal Society of Chemistry, 2008. 265 p.

50. Situ C., Mooney MH, Elliott CT, Buijs J. Advances in surface plasmon resonance biosensor technology towards high-throughput, food-safety analysis // TrAC - Trends in Analytical Chemistry. - 2010. - V. 29, No 11. - P. 1305-1315.

51. Rich RL, Myszka DG Grading the commercial optical biosensor literature-Class of 2008:'The Mighty Binders' // Journal of Molecular Recognition. 2010. - V. 23, No 1. - P. 1-64.

52. Mariani S., Minunni M. Surface plasmon resonance applications in clinical analysis // Analytical and Bioanalytical Chemistry. - 2014. - V. 406, No 910. - P. 2303-2323.

53. Choi I., Choi Y. Plasmonic nanosensors: Review and prospect // IEEE Journal of Selected Topics in Quantum Electronics. - 2012. - V. 18, No 3. - P. 1110-1121.

54. Tokel O., Inci F., Demirci U. Advances in plasmonic technologies for point of care applications // Chemical Reviews. - 2014. - V. 114, No 11. - P. 57285752.

55. Li M., Cushing SK, Wu N. Plasmon-enhanced optical sensors: a review // Analyst. - 2015. - V. 140, No 2. - P. 386-406. 